\title{
The salt tolerance of vegetable paprika varieties
}

\author{
Slezák, K., Terbe, I., Kappel, N. and Tóth, K. \\ Szent István University, Department of Vegetable and Mushroom Growing; Budapest \\ H-1118 Budapest, Ménesi út 44.
}

\begin{abstract}
Summary: In our experiments, we have chiefly tested the salt sensitivity of sweet pepper varieties. In cold forcing, $0.31 /$ plant nutrient solutions of different $\mathrm{NaCl}$ content were given twice weekly. $\mathrm{EC}$ of the nutrient solutions containing $0.25 \%$ Volldünger Linz complex fertilizer was made up to $6,10,14$ and $18 \mathrm{mS} / \mathrm{cm}$, respectively, by $2.51 / 9.17 / 17.97 / 26.76 \mathrm{~g} / \mathrm{m}^{2}$ doses of pharmacopeal $\mathrm{NaCl}$ every week. The solution used for the control treatment contained Volldünger only (EC $4.4 \mathrm{mS} / \mathrm{cm})$. Irrigation was made with pure water (EC $0.6 \mathrm{mS} / \mathrm{cm})$ when necessary.

The varieties chosen for the experiments were the following: Fehérözön, HRF F, Syn. Cecei (of white, conical fruit), Boni (of white, blunt, infolded fruit), Titán $\mathrm{F}_{1}$ (of pointed, hot fruit) and Pritavit $\mathrm{F}_{1}$ (of tomato shaped fruit).

In general, the symptoms caused by $\mathrm{NaCl}$ treatments (with doses higher than $10 \mathrm{~g} / \mathrm{m}^{2}$ weekly) have been the following:

- They have reduced the leaf area, the height of the plants, the total and the early yield, the number of fruit set per square meter, the average weight of the fruit (and, in some measure, fruit length, too) and the thousand seed weight.

- They have increased the calcium and the chlorine content of the leaves and fruits and the dry matter content of the fruits.

- They haven't affected the dry matter content of the leaves, the nitrogen, phosphorus and potassium content of the leaves and fruits, and the germinating ability of the seed.

- The effect on stem diameter and on seed production per fruit has been contradictory in some cases.
\end{abstract}

The effects of the intermediate treatments haven't been explicit in several cases.

The results of the examination of cuticular secretion have indicated the increase of the sodium and chlorine content of the leaves. This can be important in field growing where the rainwater may wash out a part of sodium and chlorine from paprika leaves.

The hot, pointed variety and the tomato shaped paprika haven't shown clearly higher salt tolerance than the varieties of white fruit colour.

Key words: $\mathrm{NaCl}$, paprika, salt tolerance, salt content of fertilizer solution, white fruited paprika varieties

\section{Introduction}

The high salt content of the soils and irrigation waters has drawn increasing attention to the study of salt stresses affecting the plants and to the investigation of the possibilities of eliminating or reducing their adverse effects. The majority of researches deals with the high salt content of the irrigation water and nutrient solution, respectively, and a great number of investigations deals with the deleteriously high salt content of the soil.

Experiments have proved the diminution of seed germinating capacity (Fischer 1985, Smith \& Cobb 1991, Meng et al. 1999) and the protraction of germination (Schmidhalter 1985, Hashem et al. 1991) under salt effect. Plant height, stem diameter, leaf area, root length, fresh weight, root/shoot ratio diminish as consequences of salt stress in the seedling stage (Meng et al. 1999).

The effect of later salt stress both on the vegetative and the generative development of the plants has been proved.

„Burning" (browning) of the roots, the reduction of root growth and root weight often occur (Bergmann 1979, Van der Beek \& Ltifi 1991, Simons et al. 1994, Terbe 1995a,
Akinci 1999). The damaged root system is unable to meet the plant's basic demands, the plants are withering and wilting in serious cases (Filius 1994, Terbe 1999). In less severe cases than lethal, the foliage turns deep green, the middle of the young shoots grows dark, the length growth stops (Terbe 1977, Bergmann 1979). The stem becomes thin, the leaves become small, narrow, hard to the touch (Terbe 2001), th plants develop few leaves in many cases (Grünberg et al. 1995. Mohammad et al. 1998). All this leads to the diminution of the leaf area (Tadesse et al. 1999, Akinci 1999, Hamdy 1988, del Amor et al. 1998). Somos (1971) and Terbe (1999) mention the scorching of the leaves and the becoming yellow of the leaf margins.

Flower production and fruit settings change together with the weakening of the plants caused by salt stress (Grünberg et al. 1995), the fruits get small, turn red early (Tadesse et al. 1999) and blossom end may be observed as a consequence of insufficient Ca uptake (Terbe 1977, Sonneveld 1979). Fruit quality improves, mainly because of changes in the nutritional value (Mizrahi \& Pasternak 1985, Villora et al. 1999).

The visible changes result from the biochemical processes, of course. Salt stress impedes photosynthesis and 
protein synthesis. Soluble carbohydrates, amino acids and similar compounds accumulate in the cells (Maksimov 1951, Wyn Jones - Gorham 1983, Meng et al. 1999, Soliman \& Doss 1992, Katz-Tal 1980). Heavy water losses occur as a consequence of the insufficient activity of the guard cells of the stoma (Maksimov 1951), that worsens the disorders in the water regime caused by the poor root activity. In general, the dry matter content of the shoots and fruits increases (Meng et al 1999, Tadesse et al. 1999). The ratio of the different sugars changes, too (Rathert 1984, Villora et al. 1999). The activity of stress enzymes, especially that of peroxidase enzyme increases (Mohammad et al 1998, Sinelnikova et al. 1986, Szalai 1994, Sancho et al. 1996).

The element composition of the plants changes, too, however, literature is contradictory in the case of several elements (p. ex. P, K) (Hamdy 1988, Gómez et al. 1996, Graifenberg et al. 1996). The $\mathrm{Na}$ and $\mathrm{Cl}$ content considerably increases in the plants exposed to $\mathrm{NaCl}$ effect (Pinkau et al. 1985, Cornillon \& Palloix 1995) generally, however, not in the same degree in the different organs, according to the different defence strategies of the plant species (Cornillon \& Palloix 1995, Soliman \& Doss 1992).

The salt sensitivity of plant species is different, of course. Consequently, the appearance of the changes mentioned above may not be generalized for the whole vegetable kingdom. In Hungary, the most common classification distinguishes three groups of vegetables according to salt tolerance, with attention to practical aspects, too (Terbe 1995b). Cucumber, melon, lettuce, white fruited paprika, carrot, parsley, radish belong to the most sensitive group. Cole crops, celeriac, spinach, red beet, chard, asparagus and chive are relatively tolerant. Other vegetables - among others, pointed-end paprika, too- can be taken as medium tolerant.

Other classification may be found in foreign scientific literature in some cases (Akinci 1999, Maas \& Hoffman 1977). Several species known as salt sensitive in our country, are taken for more salt tolerant. The contradictory estimation may be due to the different sensitivity of the varieties in most cases (Van der Beek \& Ltifi 1991, Fischer 1985, Terbe 1995a).

The salt sensitivity of the species and varieties may be influenced by many factors, such as the age of the plants (Terbe 1999), the distinct effect of the diverse salts (Sonneveld 1979, Terbe 1981, Schmidhalter 1985), the temperature (Schmidhalter 1985, Terbe 1981).

Planning and carrying out our experiments were aimed at determining the upper limit of permissible salt content in the fertilizer solution given regularly to conical, white fruited paprika varieties, in order to avoid yield losses. Further, which parameters indicate the harmful effects of salt.

\section{Material and method}

The experiments were carried out with six paprika varieties $\left(\mathrm{HRF} \mathrm{F}_{1}\right.$, Fehérözön, Syn. Cecei - of white, conical fruits, Boni - of blocky type, Titán $\mathrm{F}_{1}$ - pointed, Pritavit $\mathrm{F}_{1}$ - tomato shaped) grown in containers in an unheated plastics house at the Experimental Farm of Szent István University, Faculty of Horticultural Science in the years 1999 and 2000. The containers were filled with lowmoor peat: sand mixture ( $2: 1$ volume). The $\mathrm{EC}_{\mathrm{e}}$ of the mixture was $0.68 \mathrm{mS} / \mathrm{cm}$ at the date of transplant setting.

Planting density was 7.2 plants per square meter in both years, without pruning in the first year and with pruning of the indeterminate varieties in the second year.

For testing salt sensitivity, 0.31 of nutrient solution containing $0.25 \%$ Volldünger Linz complex fertilizer ( $\mathrm{EC}=4.4 \mathrm{mS} / \mathrm{cm}$ ), made up with $\mathrm{NaCl}$ to $6,10,14$ and 18 $\mathrm{mS} / \mathrm{cm} \mathrm{EC}$, respectively, was given twice weekly (this amounts to $0 ; 2.51 ; 9.17 ; 17.97 ; 26.76 \mathrm{~g} / \mathrm{m}^{2} \mathrm{NaCl}$ weekly).

The electric conductivity values of the soil measured at the end of the experiments are shown in Table 1.

Table 1 Electric conductivity of the soil extract at the end of the experiments

\begin{tabular}{|l|c|c|}
\hline \multirow{2}{*}{ Treatment } & \multicolumn{2}{|c|}{ Soil EC $(\mathrm{mS} / \mathrm{cm})$} \\
\cline { 2 - 3 } & 1999. & 2000. \\
\hline I. $(4.4 \mathrm{mS} / \mathrm{cm})$ & 1.80 & 1.11 \\
II. $(6.0 \mathrm{mS} / \mathrm{cm})$ & 1.93 & 1.12 \\
III. $(10.0 \mathrm{mS} / \mathrm{cm})$ & 3.08 & 1.38 \\
IV. $(14.0 \mathrm{mS} / \mathrm{cm})$ & 3.65 & 1.60 \\
V. $(18.0 \mathrm{mS} / \mathrm{cm})$ & 3.80 & 2.77 \\
\hline
\end{tabular}

The parameters measured in the course of the experiments were the following

- Vegetative plant parts: stem diameter, height, leaf area, dry matter content of the leaves, elementary composition /N - by Kjeldahl method (Erdey 1966), P - by spektrophotometry (Thamné et al. 1968), K - by flame photometry (Lásztity \& Rónai 1982), Ca, Na - by atomabsorption spektrophotometry (Lásztity \& Törley 1987), Cl - by precipitation titration (KGST 1968)/, cuticular secretion (Szalai 1994),

- Generative parts: yield per square meter (early and total yield), number of fruits set, number of market ripe fruits, fruit length, fruit diameter (measured at the fruit shoulder), fruit weight, fruit volume, number of deformed and diseased fruits, dry matter content, elementary composition ( $\mathrm{N}, \mathrm{P}, \mathrm{K}, \mathrm{Ca}, \mathrm{Cl}$ ), seed yield, thousand seed weight, germinating capacity (MSZ 6354-3:1991 M1.).

The results have been evaluated by statistical analyses (variance analysis, comparisons by pairs), too.

\section{Results and discussion}

\section{Analysis of the vegetative parts}

The diameter of the stem above the root neck hasn't shown explicit correlation with the variation of the $\mathrm{Na}$ 
content in the nutrient solution. As compared to the control treatment, stem diameter was bigger on medium salt level at several dates of measurement, especially in the determinate growing variety Fehérözön. Diminution in stem diameter ( 1 to $12 \%$ ) has been found merely in the treatment of the highest salt level $(6.194 \mathrm{~g} \mathrm{NaCl}, \mathrm{EC} 18 \mathrm{mS} / \mathrm{cm})$.

Thus, the stem diameter didn't indicate the phenomenon of becoming thin, regarded characteristic for salt damage in vegetable growing practice and in technical literature, too (Terbe 2001). The results are similar to the conclusions of Cruz et al. (1999). They have never found definite differences caused by salt treatment in the stem diameter of several tomato species.

In 1999, the results of measuring the total leaf area in the different treatments showed great dispersion in the series (repetitions) in most cases. The increasing salt concentrations have produced fluctuating changes in the averages of every single treatment. The application of the solution of medium salt content increased the leaf area of the Syn. Cecei variety by $19.2 \%$ as compared to the control. The leaf area of the plants decreased with higher salt concentrations but the varieties responded differently (10.8$30.7 \%$ ). The results are similar to the observations of Tadesse et al. (1999) on paprika and to the results of other authors with other vegetative species (Hamdy 1988, Del Amor 1998). In the varieties HRF $F_{1}$ and Pritavit $F_{1}$ initial regression was found. Later, the average leaf area increased, however, it didn't reach the control (it was by 3-6\% smaller than the control).

The average length of the main stem diminished because of the salt treatment in almost every case (by 13.2 to $22.4 \%$ in two treatments of the highest salt level) according to the measurements in 2000. The results haven't been confirmed by statistical analyses, however, they correspond to findings with paprika (Terbe 1977) and with melons (Del Amor et al. 1988).

The dry matter content of the leaves weren't altered by the treatments in any of the years, in contradiction of the literature.

The nitrogen, phosphorus and potassium content of the lower and upper leaves of the plants didn't change considerable by the salt treatments.

The calcium and chlorine content in the leaves of the variety Feehérözön increased by the salt treatments (Figures I and 2). The increase of calcium content in the lower leaves and in the upper ones found at both dates of analysis in the treatment of the highest salt content (112.1-130.2\% as compared to the control) is in contradiction with the results of Cornillon and Palloix (1995) and of Gómez et al. (1996). The increase in chlorine content (107.0-280.3\%) was very high. Chlorine increase was found by Pinkau et al. (1985), too, in the top of leek, cabbage and carrot plants treated with $\mathrm{NaCl}$.

In the course of the examination of cuticular secretion we have observed the leakage of sodium and chlorine from the leaves. This may be especially important in field growing where the rainwater may wash out a part of the secreted sodium and chlorine.

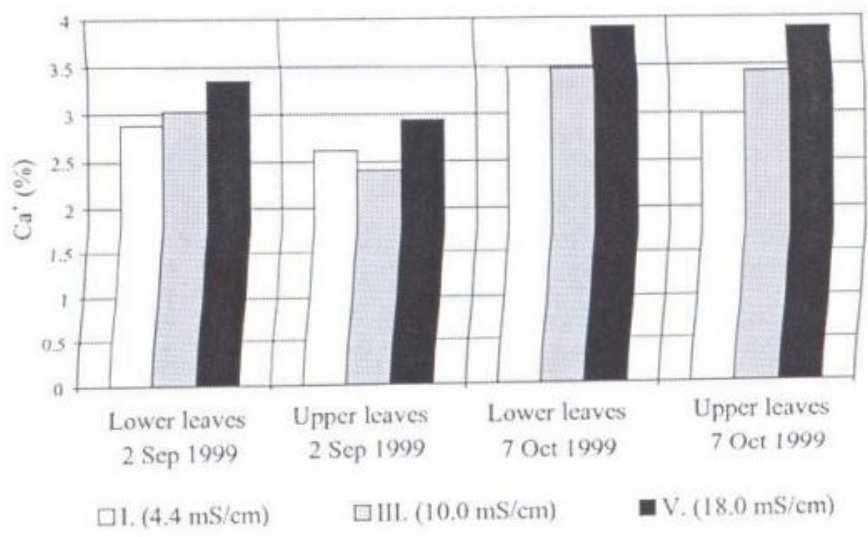

Figure I Changes in the calcium content of the variety Fehérözön

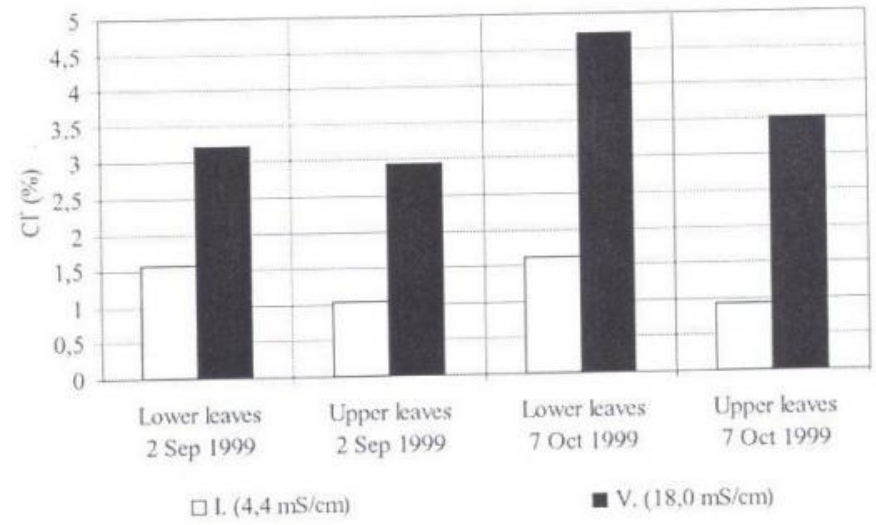

Figure 2 Changes in the chlorine content of the variety Fehérözön

\section{Analysis of the generative parts}

The treatments of high salt level have reduced the early and the total yield as well as the average daily weight increase of the fruits (Tables 2 and 3 ). $18 \mathrm{mS} / \mathrm{cm}$ reduced early yield by $13.0-40.4 \%$, total yield by $16.3-33.4 \%$, average daily fruit weight increase by $13.0-37.0 \%$. The decrease was statistically significant on $95-99 \%$ level in numerous cases. The results measured in the intermediate treatments have shown differences according to varieties. Especially in the variety Fehérözön, these treatments didn't lag behind the control, moreover, they surpassed it in one of the years. The pointed, hot Titán $\mathrm{F}_{1}$ and the tomato shaped Pritavit $\mathrm{F}_{1}$ responded to the salt treatments like the white varieties.

The average number of fruit sets per square meter as well as the number of the fruits that have reached market ripeness, diminished in general in the treatments of high sodium level (at the highest level by $20 \%$ in several cases but statistically not proved because of the great dispersion of the data). However, these parameters showed an improvement in the varieties Fehérözön and Syn. Cecei with the nutrient solution of $0.582 \mathrm{~g} \mathrm{NaCl}$ content in the second year of the experiment.

The average length of the fruits diminished with the higher salt doses (by $2.4-12.6 \%$ ) but the diminution hasn't 
been statistically provable. The treatments of medium salt level caused in some cases a slight elongation of the fruit (by $0.6-4.7 \%$ ).

The salt treatment hadn't any effect on fruit diameter (measured at the fruit shoulder). Statistically significant decrease in the length/diameter ratio was found only in the variety Titán $\mathrm{F}_{1}(11 \%)$ in the first year of the trial.

Reduction in the average fruit weight, like in yield and in fruit length - was found in the higher salt treatments (in several cases statistically proved). Small fruit mass increase was observed in several varieties with the solution containing less $\mathrm{NaCl}$.

Figure 3 shows the average fruit diameter, fruit length and fruit weight of HRF F1, as compared to the control.
The number of deformed and diseased fruits hasn't increased in every treatment. Several plots have shown considerable dispersion. In some varieties, deformed and diseased fruits were found in the control plots, while none were found in several treatments of high salt level. The very probable conclusion can be drawn that the symptoms may be produced by other environmental effects and not by salt treatment.

The dry matter content has increased in almost each treatment. Figure 4 demonstrates the changes in the dry matter content of the variety Fehérözön. Tadesse et al. (1999) have published similar results on the dry matter content of paprika fruits grown with increasing $\mathrm{KCl}$ doses applied to plants cultivated by the NFT (Nutrient Film Technique) system.

Table 2 Total yield

\begin{tabular}{|c|c|c|c|c|c|c|}
\hline \multirow[t]{2}{*}{ Variety } & \multirow[t]{2}{*}{ Year } & $\begin{array}{c}\text { I. } \\
(4.4 \mathrm{mS} / \mathrm{cm})\end{array}$ & $\begin{array}{c}\text { II. } \\
(6.0 \mathrm{mS} / \mathrm{cm}) \\
\end{array}$ & $\begin{array}{c}\text { III. } \\
(10.0 \mathrm{mS} / \mathrm{cm}) \\
\end{array}$ & $\begin{array}{c}\text { IV. } \\
(14.0 \mathrm{mS} / \mathrm{cm}) \\
\end{array}$ & $\begin{array}{c}\mathrm{V} . \\
(18.0 \mathrm{mS} / \mathrm{cm}) \\
\end{array}$ \\
\hline & & \multicolumn{5}{|c|}{ Total yield $\left(\mathrm{kg} / \mathrm{m}^{2}\right)$} \\
\hline \multirow[t]{2}{*}{ HRF FI } & 1999 & 3.60 & 3.06 & 2.32 & 2.18 & 2.87 \\
\hline & 2000 & 7.20 & 6.44 & 6.19 & 5.69 & 5.01 \\
\hline \multirow[t]{2}{*}{ Fehérözön } & 1999 & 2.69 & 2.82 & 2.50 & 2.51 & 2.24 \\
\hline & 2000 & 9.24 & 10.39 & 9.30 & 8.99 & 7.25 \\
\hline \multirow[t]{2}{*}{ Syn. Cecei } & 1999 & 2.93 & 2.74 & 2.58 & 2.43 & 1.95 \\
\hline & 2000 & 8.59 & 7.86 & 5.80 & 6.39 & 6.44 \\
\hline \multirow[t]{2}{*}{ Boni } & 1999 & 3.78 & 3.10 & 2.20 & 2.22 & 2.34 \\
\hline & 2000 & 8.18 & 8.10 & 6.86 & 6.53 & 4.27 \\
\hline \multirow[t]{2}{*}{ Titán F1 } & 1999 & 3.06 & 2.67 & 2.46 & 2.12 & 1.94 \\
\hline & 2000 & 7.09 & 6.32 & 5.28 & 5.04 & 4.38 \\
\hline \multirow[t]{2}{*}{ Pritavit F1 } & 1999 & 2.30 & 2.59 & 2.33 & 2.05 & 2.02 \\
\hline & 2000 & 6.21 & 5.14 & 5.54 & 4.08 & 3.83 \\
\hline
\end{tabular}

Table 3 Calculated average yield increase per day $(\mathrm{g})$ in the different treatments

\begin{tabular}{|c|c|c|c|c|c|c|c|c|c|c|c|}
\hline \multirow[t]{2}{*}{ Variety } & \multirow[t]{2}{*}{ Year } & \multicolumn{2}{|c|}{$\begin{array}{c}\mathrm{l} . \\
(4.4 \mathrm{mS} / \mathrm{cm})\end{array}$} & \multicolumn{2}{|c|}{$\begin{array}{c}\text { II. } \\
(6.0 \mathrm{mS} / \mathrm{cm}) \\
\end{array}$} & \multicolumn{2}{|c|}{$\begin{array}{c}\text { III. } \\
(10.0 \mathrm{mS} / \mathrm{cm}) \\
\end{array}$} & \multicolumn{2}{|c|}{$\begin{array}{c}\text { IV. } \\
(14.0 \mathrm{mS} / \mathrm{cm})\end{array}$} & \multicolumn{2}{|c|}{$\begin{array}{c}\mathrm{V} . \\
(18.0 \mathrm{mS} / \mathrm{cm})\end{array}$} \\
\hline & & AYI & $\mathrm{R}^{2}$ & AYI & $\mathrm{R}^{2}$ & AYI & $\mathrm{R}^{2}$ & AYI & $\mathrm{R}^{2}$ & AYI & $\mathrm{R}^{2}$ \\
\hline \multirow[t]{2}{*}{ HRF F1 } & 1999 & 46.70 & 0.947 & 39.93 & 0.987 & 29.04 & 0.986 & 28.53 & 0.994 & 38.05 & 0.998 \\
\hline & 2000 & 58.01 & 0.967 & 49.83 & 0.956 & 50.94 & 0.963 & 47.58 & 0.959 & 41.90 & 0.966 \\
\hline \multirow[t]{2}{*}{ Fehérözön } & 1999 & 35.30 & 0.901 & 38.72 & 0.992 & 34.48 & 0.972 & 36.01 & 0.984 & 30.73 & 0.995 \\
\hline & 2000 & 68.69 & 0.972 & 78.99 & 0.968 & 68.68 & 0.966 & 72.18 & 0.960 & 57.67 & 0.969 \\
\hline \multirow[t]{2}{*}{ Syn. Cecei } & 1999 & 36.47 & 0.977 & 36.48 & 0.980 & 32.40 & 0.996 & 29.14 & 0.980 & 22.96 & 0.980 \\
\hline & 2000 & 65.81 & 0.996 & 60.01 & 0.995 & 39.60 & 0.980 & 45.02 & 0.974 & 48.63 & 0.991 \\
\hline \multirow[t]{2}{*}{ Boni } & 1999 & 53.83 & 0.961 & 47.01 & 0.995 & 31.30 & 0.985 & 30.72 & 0.998 & 32.94 & 0.994 \\
\hline & 2000 & 62.66 & 0.974 & 61.53 & 0.980 & 55.18 & 0.981 & 52.97 & 0.988 & 34.61 & 0.928 \\
\hline \multirow[t]{2}{*}{ Titán F1 } & 1999 & 43.02 & 0.970 & 36.26 & 0.985 & 32.21 & 0.992 & 27.34 & 0.960 & 24.40 & 0.960 \\
\hline & 2000 & 51.75 & 0.977 & 47.18 & 0.958 & 42.16 & 0.963 & 39.08 & 0.969 & 35.03 & 0.953 \\
\hline \multirow[t]{2}{*}{ Pritavit F1 } & 1999 & 35.83 & 0.804 & 39.78 & 0.999 & 37.67 & 0.988 & 32.65 & 0.996 & 33.00 & 0.990 \\
\hline & 2000 & 54.85 & 0.882 & 44.01 & 0.913 & 52.73 & 0.918 & 36.74 & 0.904 & 34.29 & 0.921 \\
\hline
\end{tabular}

$\mathrm{AYI}=$ average yield increase per day $(\mathrm{g})$

$\mathrm{R}^{2}=$ variance of the linear regression of the cumulative average yield data series 


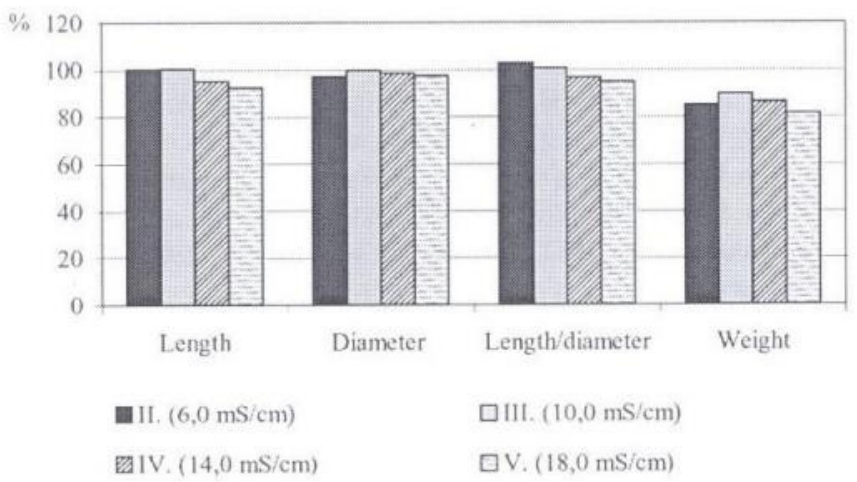

Figure 3 Physical characteristics of the fruits in the variety HRF F (2000) $_{1}$ (Control $=100 \%)$

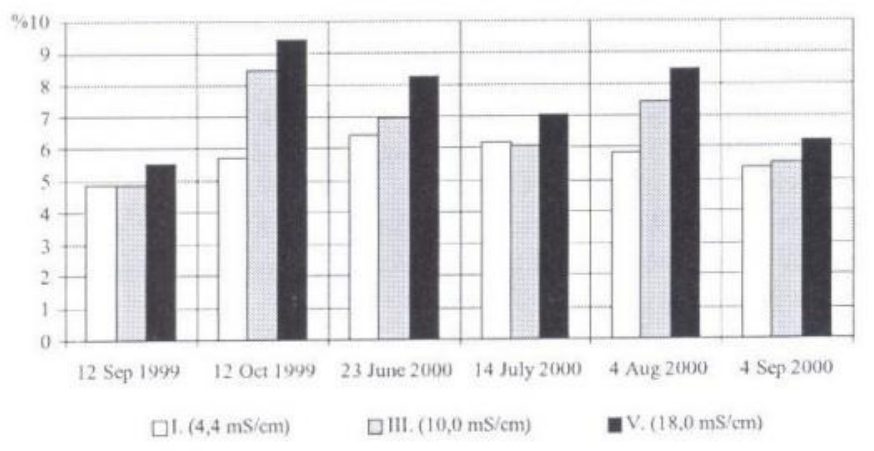

Figure 4 The dry matter content of the variety Fehérözön

There hasn't been found any significant change in the nitrogen, phosphorus and potassium content of the fruits due to the salt treatment. The calcium content however, has shown an increase of $15-17 \%$ as compared to the control in the variety Fehérözön (similarly to the results of Gómez et al, published in 1966) and there hasn't been any difference between the treatments of 10 and $18 \mathrm{mS} / \mathrm{cm} \mathrm{EC}$. In the variety Titán F1 a small increase of $9 \%$ was measured in only one of the samples. Chlorine content of Fehérözön fruits was 90 to 125 per cent higher in the treatment 18 $\mathrm{mS} / \mathrm{cm}$ than in the control.

In sensory analysis, the jury preferred in $\mathrm{HRF} \mathrm{F}_{1}$ the fruits of the plants treated with a solution of $14 \mathrm{mS} / \mathrm{cm}$ EC, however, the fruits of the control plants were not much behind. From the other varieties, the control plants were held best, but in Syn. Cecei practically no difference was found between the first and the second level of treatment.

The seed yield of the fruits picked at full ripeness hasn't shown explicit correlation to the salt content of the nutrient solution. The laboratory tested germinating ability of the seed did not change, indicating that the salt treatment didn't impair the proliferation of the plants. The thousand seed weight was significantly lower in the salt treatments than in the control, with the exception of the variety Boni. The decrease didn't coincide with the increase in salt content. It was of different rate (in several cases insignificant, but in some varieties higher than 20\%) (Table 4).

On the basis of the observations made in the paprika forcing experiment it can be stated that the treatments with $\mathrm{NaCl}$, higher than $10 \mathrm{~g} / \mathrm{m}^{2}$ :

- have reduced the leaf area, the height of the plants, the total and the early yield, the fruit set number per square meter, the average weight of the fruit (and, in some measure, fruit length, too) and the thousand seed weight.

- They have increased the calcium and the chlorine content of the leaves and fruits and the dry matter content of the fruits.

- They haven't affected the dry matter content of the leaves, the nitrogen, phosphorus and potassium content of the leaves and fruits and the germinating ability of the seed.

- The effect on stem diameter and on seed production per fruit has been contradictory in some cases.

The effects of the intermediate treatments haven't been explicit in several cases.

The hot, pointed variety and the tomato shaped paprika haven't shown clearly higher salt tolerance than the varieties of white fruit colour.

Table 4 Thousand seed weight $(\mathrm{g})$ produced in the experiments

\begin{tabular}{|c|c|c|c|c|c|c|}
\hline Variety & Year & $\begin{array}{c}1 . \\
(4,4 \mathrm{mS} / \mathrm{cm})\end{array}$ & $\begin{array}{c}\text { II. } \\
(6,0 \mathrm{mS} / \mathrm{cm})\end{array}$ & $\begin{array}{c}\text { III. } \\
(10,0 \mathrm{mS} / \mathrm{cm})\end{array}$ & $\begin{array}{c}\text { IV. } \\
(14,0 \mathrm{mS} / \mathrm{cm})\end{array}$ & $\begin{array}{c}\mathrm{V} . \\
(18,0 \mathrm{mS} / \mathrm{cm})\end{array}$ \\
\hline \multirow[t]{2}{*}{ HRF F1 } & 1999 & 8.81 & 7.63 & 7.98 & 7.20 & 7.84 \\
\hline & 2000 & 7.08 & 6.78 & 6.88 & 6.49 & 6.32 \\
\hline Fehérözön & 1999 & 7.54 & 6.72 & 6.03 & 5.63 & 6.75 \\
\hline \multirow[t]{2}{*}{ Syn. Cecei } & 1999 & 7.92 & 7.42 & 7.66 & 7.88 & 7.35 \\
\hline & 2000 & 7.18 & 6.39 & 7.12 & 6.20 & 6.57 \\
\hline \multirow[t]{2}{*}{ Boni } & 1999 & 7.57 & 8.94 & 7.24 & 8.12 & 8.75 \\
\hline & 2000 & 8.44 & 8.34 & 8.37 & 7.40 & 8.11 \\
\hline \multirow[t]{2}{*}{ Titán Fl } & 1999 & 9.08 & 9.07 & 9.25 & 8.17 & 8.61 \\
\hline & 2000 & 7.25 & 7.23 & 7.23 & 6.87 & 6.88 \\
\hline \multirow[t]{2}{*}{ Pritavit F1 } & 1999 & 9.62 & 8.63 & 9.02 & 7.38 & 8.92 \\
\hline & 2000 & 9.52 & 8.11 & 8.30 & 9.08 & 8.52 \\
\hline
\end{tabular}




\section{Conclusions}

The results of our experiments have led to the conclusion that increased attention must be paid to the salt sensitivity of the crop, especially regarding the following factors:

- the quality of the irrigation water,

- the choice of the fertilizer (type, purity)

- the fertilizer doses applied.

Doses of $\mathrm{NaCl}$ higher than $10 \mathrm{~g} / \mathrm{m}^{2}$ given weekly by the irrigation water are decidedly depressive to the development of paprika in forcing.

However, small doses of $\mathrm{NaCl}$, be it ever so little as 2.5 $\mathrm{g} / \mathrm{m}^{2}$ weekly, may cause considerable loss in the income.

\section{References}

Akinchi, S. \& Akinchi, I.E. (1999): Solanaceae turlerinin fide doneminde tuza tepkileri. (Responses of Solanaceae species to salt in seedling stage) Bahce. 28 (1-2): 79-86.

Amor, F.M. del, Carvajal, M., Martínez, V. \& Cerdá, A. (1998): Response of Muskmelon Plants (Cucumis melo L.) to Irrigation with Saline Water. Acta Horticulturae. 456: 263-268.

Beek, J.G. van der \& Ltifi, A (1991): Evidence for salt tolerance in pepper varieties (Capsicum annuum L.) in Tunisia. Euphytica. 57 (1): 51-56.

Bergmann, W. (1979): Termesztett növények táplálkozási zavarainak elôfordulása és felismerése. Mezôgazdasági Kiadó. Budapest.

Cruz, V., Cuartero, J., Bolarín, M.C. \& Romero, M. (1990): Evaluation of Characters for Ascertaining Salt Stress Responses in Lycopersicon Species. Journal of the American Society for Horticultural Science. 115 (6): 1000-1003.

Erdey, L. (1966): Bevezetés a kémiai analízisbe. Tankönyvkiadó. Budapest.

Filius, I. (1994): A zöldségtermesztés élettani alapjai. In: Balázs S. szerk.: Zöldségtermesztôk kézikönyve. 2., javított kiadás. Mezôgazda Kiadó. Budapest.

Fischer, I. (1985): Paprika sótürése és exocarpium-vastagsága. Kertgazdaság. 17 (1): 57-61.

Gómez, I., Navarro Pedreno, J., Moral, R., Iborra, M.R., Palacios, G. \& Mataix, J. (1996): Salinity and Nitrogen Fertilization affecting the Macronutrient Content and Yield of Sweet Pepper Plants. Journal of Plant Nutrition. 19 (2): 353-359.

Graifenberg, A., Botrini, L., Giustiniani, L. \& Lipucci di Paola, M. (1996): Salinity Affects Growth, Yield and Elemental Concentration of Fennel. HortScience. 31 (7): 1131-1134.

Grunberg, K., Fernandez-Munoz, R., Cuartero, J. \& GomezGuillamon, M.L. (1995): Growth, flowering, and quality and quantity of pollen of tomato plants grown under saline conditions. Acta Horticulurae. 412: 484-489.

Hamdy, A. (1988): Plant Growth and Nutrient Uptake Under Different Application Modes of Saline Water (part 2). Proccedings $15^{\text {th }}$ ICID European Regional Conference. 2: 144-156.

Hashem, MM., Abou-Hadid, AF. \& El-Beltagy, AS. (1991): Studies on the germination ability and seedling growth of pepper (Capsicum annuum) growing in Egypt at high salinity. Egyptian Journal of Horticulture. 18 (1): 87-94.

Katz, A. \& Tal, M. (1980): Salt tolerance in the wild relatives of the cultivated tomato: proline accumulation in callus tissue of Lycopersicon esculentum and L. peruvianum. Pflanzenphysiologie 98 (5): 429-435
KGST Egységes vizsgálati módszerek. Kémiai módszerek I. 1968. Vízgazdálkodási Tudományos Kutató Intézet. Budapest.

Lásztity R. \& Törley D. (1982): Élelmiszerkémia és technológiai gyakorlatok. Tankönyvkiadó. Budapest.

Lásztity, R. \& Törley, D. szerk. (1987): Alkalmazott élelmiszeranalitika. I. kötet. Mezógazdasági Kiadó. Budapest.

Makszimov, N.A. (1951): A növényélettan rövid tankönyve. Tankönyvkiadó. Budapest.

Maas, E. V. \& Hoffmann, G.J. (1977): Crop Salt Tolerance Current Assessment. Journal of the Irrigation and Drainage Division. 103: 115-134.

Meng, H.W., Cui, H.W., Zhang, Y.F. \& Zhang, M. (1999): Physiological effects of $\mathrm{NaCl}$ stress on cucumber germination and seedling growth. Report Cucurbit Genetics Cooperative. 22: 11-13. Mizrahi, Y. \& Pasternak, D. (1985): Effect of salinity on quality of various agricultural crops. Plant and Soil. 89 (1-3): 301-307.

Mohammad, M., Shibli, R., Ajlouni, M. \& Nimri, L. (1998): Tomato root and shoot to salt stress under different levels of phosphorus nutrition. Journal of Plant Nutrition. 21 (8): $1667-1680$.

Pinkau, H., Türk, D. \& Poser, Ch. (1985): Auswirkung der Beregnung mit Ostseewasser bei Gemüse auf Pflanze, Boden und Grundwasser. Archiv für Gartenbau. 33 (2): 89-98.

Rathert, G. (1984): Sucrose and starch content of plant parts as a possible indicator for salt tolerance of crops. Australian Journal of Plant Physiology. 11 (6): 491-495

Sancho, M.A., Forchetti, S.M. de, Pliego, F., Valpuesta, V. \& Quesada, M.A. (1996): Peroxidase activity and isoenzymes in the culture medium of $\mathrm{NaCl}$ adapted tomato suspension cells. Plant Cell, Tissue and Organ Culture. 44: 161-167.

Schmidhalter, U. (1985): Effet de la salinité et de divers autres facteurs sur la germination des carottes (Sótartalom és más különbözố tényezốk hatása a sárgarépa csírázására). Revue Suisse de Viticulture Arboriculture Horticulture. 1985. 17 (6): 377-380.

Simons, J.N., Simons, J. E. \& Simons, J. L. (1994): Plant stress as a predisposing factor in outbreaks of bacterial leafspot. $107^{\text {th }}$ Annual meeting of the Florida State Horticultural Society, Orlando, USA. Conference paper.

Sinelnikova, V.N., Kosareva, I. A. \& Bazhanov, I.A. (1986): Effect of soil salinity on physiological aspects of growth and yield in tomatoes. Sbornik Nauchnykh Trudov po Prikladnoj Botanike, Genetike i Selektsii. 102: 57-65.

Smith, P.T. \& Cobb, B.G. (1991): Accelerated Germination of Pepper Seed by Priming With Salt Solutions and Water. HortScience. 26 (4): 417-419.

Soliman, M.S. \& Doss, M. (1992): Salinity and mineral nutrition effects on growth and accumulation of organic and inorganic ions in two cultivated tomato varieties. Journal of Plant Nutrition. 15 (12): 2789-2799.

Somos, A. (1971): A paradicsom. Akadémiai Kiadó. Budapest. Sonneveld, C. (1979): Effect of salinity on the growth and mineral composition of sweet pepper and egg plant grown under glass. Acta Hort. Tech.Commun. ISHS. 89: 71-78.

Szalai, I. (1994): A növények élete. JATEPress. Szeged.

Tadesse, T., Nichols, MA. \& Fisher, KJ (1999): Nutrient conductivity effects on sweet pepper plants grown using a nutrient film technique. 1. Yield and fruit quality. New-Zealand Journal of Crop and Horticultural Science. 27 (3): 229-237.

Terbe, I. (1977): A paprika tápanyaghiány és mérgezési tünetei. Hajtatás, korai termesztés. 8 (3): 12-13.

Terbe, I. (1981): A szaporítóföld minốségének hatása a zöldségfélék csírázására. Kertészeti Egyetem Közleményei. 45. Különlenyomat. 49-53. 
Terbe, I. (1995a): A hajtatott paprika tápoldatozása és élettani rendellenességei. Hajtatás, korai termesztés. 26 (3): 23-24.

Terbe, I. (1995b): A fajlagos elektromos vezetốképesség (EC) mérése a gyakorlatban. Hajtatás, korai termesztés. 26 (4): 14-18.

Terbe, I. (1999): Termesztési tanácsok paprikatermesztôknek. Blondy és Társa Kft. Szentpéterszeg.

Terbe, I. (2001): Trágyázás; Fejes saláta; Spenót. In: Balázs S. szerk.: A zöldséghajtatás kézikönyve. Mezôgazda Kiadó. Budapest.
Thamm F.-né, Krámer M. \& Sarkadi J. (1968): Növények és trágyaanyagok foszfortartalmának meghatározása ammóniummolibdo-vanadátos módszerrel. Agrokémia és Talajtan Tan. 17: 1-2. Víllora, G., Moreno, D.A., Pulgar, G. \& Romero, L.M. (1999): Zucchini Growth, Yield and Fruit Quality in Response to Sodium Chloride Stress. Journal of Plant Nutrition. 22 (6): 855-861.

Wyn Jones, R.G. \& Gorham, J. (1983): Aspects of salt and drought tolerance in higher plants. Genetic engineering of plants. New York - London. 355-370. 